\title{
PAUL CLAVAL E SUA NOVA OBRA*
}

Eduardo Yázigi

Paul Claval, professor emérito do Departamento de Geografia da Sorbonne, foi agraciado com o Prêmio Vautrin Lud de 1996 - considerado equivalente do Prêmio Nobel da Geografia, outorgado a cada ano desde 1992. Monsieur Claval é considerado uma das maiores referências mundiais da Geografia, dominando questões de espaço, paisagem, economia, cidades e suas lógicas etc. Sua abordagem da Geografia Cultural fez escola pelo mundo todo. Apesar de ter passado dos oitenta anos de idade, continua em intensa produção. Um de seus últimos livros, que tive a honra de ser convidado para traduzir, leva por título em português Enobrecer e embelezar. Da arquitetura ao urbanismo texto que apresentarei aqui. Esta obra não seria possível sem que seu autor já tivesse pesquisado em profundidade várias centenas de autores e episódios da civilização, matéria-prima de suas reflexões que optaram por uma clivagem inédita e colossal. Sua análise histórica das razões da arquitetura e do urbanismo, segundo economia, sociedade, estética, natureza, tecnologias e muitos outros fatores constitui uma plataforma tão segura quanto precisa para outros pesquisadores compromissados com cientificidade poderem enveredar por abordagens mais específicas. Vale ressaltar que, ao longo de toda a obra, o autor destacou a criatividade e qualidade do momento Histórico, do Renascimento até o movimento Modernista do século passado.

A quantidade de dados e análises apresentados é tão grande que necessitaria uma apreciação que ultrapassasse a ideia de resenha, a rigor, nos moldes de um vasto artigo interpretativo e comparado. Por esta razão limito-me a apresentar a estrutura da obra, e uma consideração sobre seu valor para o Brasil em particular - país e idioma que Claval conhece muito bem.

Entre nós, a evolução do quadro urbano da arquitetura e das cidades brasileiras está a requerer novas referências históricas sobre a cultura material e os valores sociais coletivos, a fim de repensarmos políticas urbanas capazes de redefinir certo brilho que já tiveram lugar neste trópico. Muitas circunstâncias interferem na produção do espaço urbano e neste sentido Claval aponta para um modelo de análise que destrincha os fatores que os detonam. Poucos autores respondem, por exemplo, ao que Claude Levi Strauss, aqui vivendo, perguntava por qual razão nossas cidades conheciam a decadência antes do apogeu. Yves Bruand, depois de atuar vários anos como professor de Metodologia da História na USP, agraciou-nos com um belíssimo compêndio sobre a História da Arquitetura no Brasil, cuja visão de conjunto e riqueza de informações ainda não foi superada. Mais um autor, o brasileiro Sérgio Paulo Rouanet, coloca uma questão ainda não retrucada pelas esquerdas em seu livro As razões do iluminismo. Claval, sem se referir ao Brasil, demonstra o quanto as elites, o alto clero e depois os empresários pesaram nas opções enaltecedoras da cidade em colaboração com os gênios do tempo.

O que conviria trazer à baila em nível de discussão nacional nos remete ao deboche estético que domina nosso país. É inquietante

** CLAVAL, Paul. Ennoblir et embellir: de l'architecture à l'urbanisme. Paris: Les Carnets de I'Info, 2011. 296 p. Tradução para o português pessoalmente conferida e aprovada pelo autor. Entretanto, o editor francês comprou os direitos da tradução ao português, feita por mim, podendo editá-lo em qualquer país de língua portuguesa. 
o fato de muitos autores se absterem de fazer renascerem as virtudes que engrandecem a cidade não com suas soluções formais, mas com a revalorização do sentido do urbano - do espaço público, em particular -, algo assim como ética e disciplinamento dos códigos de edificação. Predomina velado um medo de discutir estética, mas se permitem obras degradantes por todas as partes. É aí que todas as associações de profissionais que intervêm na ideia de espaço, inseparável de sociedade, têm o dever se fazer presentes na teoria e na política: arquitetos, urbanistas, filósofos, paisagistas, geógrafos, sociólogos, turismólogos etc. O espaço é uma instância da sociedade!

São, enfim, preocupações de primeira ordem, carentes de urgentíssimas considerações, pois o Brasil tem sido o país mais enfeado do planeta nos anos que seguiram seu arranque industrial. Uma deterioração que não é só da arquitetura e do urbanismo, mas também da natureza, cuja ocupação não consegue evitar a favelização ou a arquitetura sem caráter, inclusive muitas delas dispendiosas. O medo atroz dos poderes municipais de perder votos, não exigindo qualidade, assim como abstenções contundentes das representações de classe devem ser debatidos sob o prisma da democracia. E, sobretudo, não nos olvidemos das afirmações de dois insignes autores que coincidem numa opinião tácita: Sim, o proletário tem direito a tudo o que é monumental, erudito e de alta qualidade, sem o quê ele não consegue criticar seu próprio periferismo. A conferir com dois clássicos: Edward Palmer Thompson, em sua colossal A formação da classe operária inglesa: a árvore da liberdade, e José de Souza Martins na revista Espaço e Sociedade, n. 42, p. $74-84$.

Dividida em três partes, cada uma com conteúdos muito bem definidos, a presente obra de Paulo Claval nos remete a:

\section{PRIMEIRA PARTE}

Emergência e triunfo do urbanismo de enobrecimento e embelezamento

\section{Uma nova ambição: enobrecer} e embelezar os quadros de vida. A história de uma redescoberta; A perspectiva linear e a mensagem do Renascimento. Alberti e o renascimento da arquitetura moderna. Da cena de teatro ao urbanismo: o itinerário do Renascimento. Do parque ao espaço urbano: um câmbio da escala no urbanismo de visão estética.

2. A cenarização da cidade e do campo no século XVII. Um urbanismo que enobrece a vida das elites. As formas e o encaminhamento do urbanismo de enobrecimento. A cenarização da cidade e da natureza na Europa continental. A cenarização da cidade e da natureza na Inglaterra.

\section{SEGUNDA PARTE}

No fim do século xviii a vontade de enobrecer o espaço se combina com a preocupação de assegurar um funcionamento eficaz

\section{A modernização do urbanismo}

funcional. $O$ urbanismo funcional nos séculos XVI e XVII. A racionalização da cidade. A racionalização da cidade e a emergência de um novo urbanismo. O manejo do território.

2. A crise do classicismo e o nascimento da modernidade. A crise da consciência europeia e a arquitetura: a querela dos /antigos e dos Modernos. A procura da arquitetura das origens. Expressão simbólica e modernidade. A arte dos jardins no último terço do século XVIII. Uma mistura de funcionalismo e ecletismo. 
3. A cenarização da cidade e o campo no século XIX. Revolução Industrial e urbanismo funcional. Democratização da sociedade e urbanismo de embelezamento. Neoclassicismo e romantismo. O embelezamento pela natureza. A síntese de Haussmann. De Haussmann ao movimento "City Beautiful", nos Estados Unidos.

\section{TERCEIRA PARTE}

O fim do urbanismo de enobrecimento e o enobrecimento e embelezamento

1. Técnicas, estética, concepções sociais: as mutações do final do século XIX. Técnicas que transformam o espaço urbano. Novas concepções de embelezamento. Urbanismo, reforma moral e reforma social.

\section{O nascimento do urbanismo}

moderno. A procura de quadros de referências estéticas. A análise dos problemas sociais. Repensar a cidade: o exemplo de Patrick Geddes. Urbanismo e planejamento de cidades.

3. O urbanismo dos congressos internacionais de arquitetura moderna. Estéticas da sensibilidade. Conclusão. Bibliografia. 